\title{
Transcription of Genes Involved in Biomineralization in Two Mantle Morphs of Pearl Oyster, Pinctada Persica
}

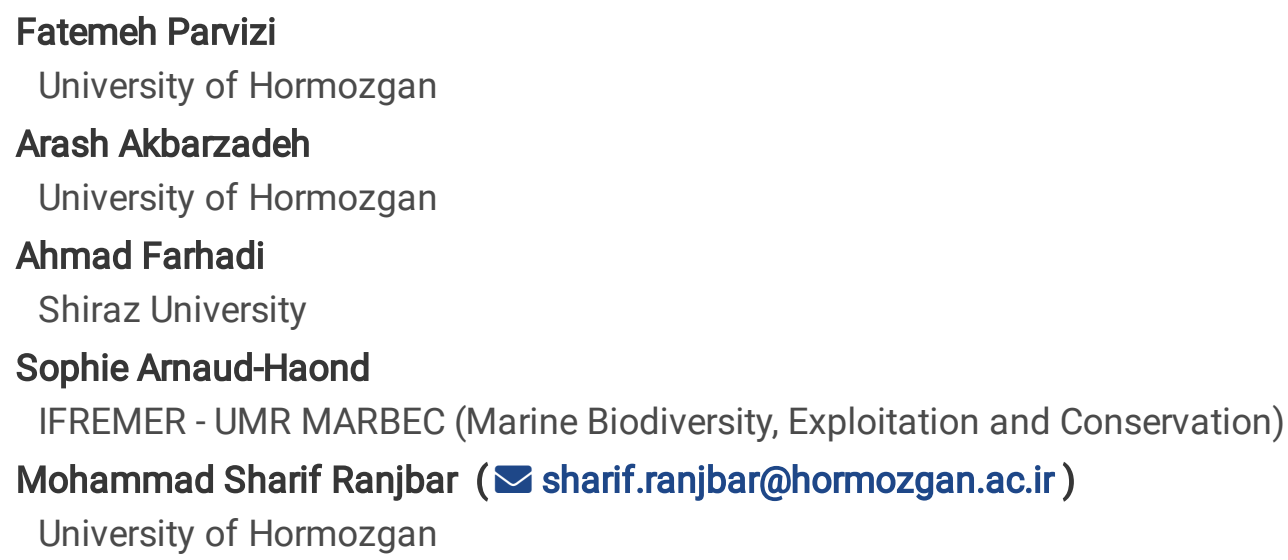

Fatemeh Parvizi

University of Hormozgan

Arash Akbarzadeh

University of Hormozgan

Ahmad Farhadi

Shiraz University

Sophie Arnaud-Haond

IFREMER - UMR MARBEC (Marine Biodiversity, Exploitation and Conservation)

Mohammad Sharif Ranjbar ( $\sim$ sharif.ranjbar@hormozgan.ac.ir)

University of Hormozgan

\section{Research Article}

Keywords: Gene expression, Mantle color, Biomineralization, Nacre, qRT-PCR, Pearl oyster.

Posted Date: August 12th, 2021

DOI: https://doi.org/10.21203/rs.3.rs-789458/v1

License: (c) (i) This work is licensed under a Creative Commons Attribution 4.0 International License. Read Full License 


\section{Abstract}

A few species of mollusks display color variation in their soft tissues. In pearl oysters, the color polymorphism in mantle tissue is associated with the color and radiance of shell and pearl. The study of biomineralization related genes in mantle tissue of pearl oysters can be used as a suitable approach to better identify the molecular mechanisms that influence shell and pearl quality and color variations. In this study, we investigated the transcription of biomineralizationrelated genes in black and orange mantle morphotypes of pearl oyster, Pinctada persica in both warm and cool seasons using quantitative real-time PCR. Our results showed that the genes involved in biomineralization of the prismatic and nacre layer, i.e.; ASP, KRMP, MRNP34, SHELL, SHEM1B, LINKINE, PIF, SHEM5, NACREIN, and in pigmentation (TYR2A) were significantly highly expressed in orange phenotype compared to those of black one, suggesting the existence of different genetic processes between two color morphs of mantle tissue and the more active role of genes in orange morphotype. In black mantle phenotype, ASP, KRMP, SHEM5 and PIF and in the orange phenotype, only KRMP and $P R I S M$ showed difference in seasonal expression. This study provides an accurate understanding of the mantle trait of P. persica.

\section{Introduction:}

Pearl oysters occur around the world with considerable variation in the shell and pearl phenotype in each species 1.2. Although the shell color variation in intra and inter species of mollusks is common, color variation in soft tissues has been reported for only few species 3. For example, the black-lip pearl oyster (Pinctada margaritifera), a widely distributed Indo-Pacific pearl oyster species, consists of three distinct phenotypic color morphs of mantle tissue i.e., black, albino, and orange 4-6. However, the individuals with black mantle phenotype are the most frequent, and the albino and orange morphotypes are rare mutants 3. On the contrary, Pinctada persica which is the most important pearl oyster species of Persian Gulf, displays two mantle color morphotypes, orange and black, but the black phenotype is rare and the orange morphotype is found at higher frequencies 7. P. persica was previously known as P. margaritifera var. persica (Linnaeus, 1758), but recently has been recognized as a new species 8 . The cross examination on $P$. margaritifera demonstrated that the variations in mantle color follow the Mendelian inheritance pattern 3. Ky et al (2019) showed that the orange allele of $P$. margaritifera is recessive to the black one 9 , and therefore the black mantle color is the dominant morphotype of the species. It is likely that the black phenotype of $P$. persica is the mutant phenotype, but it should receive more researches attention.

In pearl oysters, the color polymorphism of mantle tissue is tightly linked to the color and radiance of shell and pearl. Color variation of nacre is a combined result of genes involved in the biomineralization of the nacreous and prismatic layers and the synthesis of pigments such as melanin, suggesting that color polymorphism takes place at different levels in the shell structure 10. Biomineralization (also termed as biocalcification), is a key physiological process for depositing calcium carbonate (CaCO3) in marine calcifiers 11.12. The mantle tissue includes the important transcriptional activity of biomineralization genes and secretes biomineral proteins, leading to shell and pearl formation. These proteins can also affect the color of shell and pearl in pearl oysters 13-20.

The transcriptome study of biomineralization related genes in mantle tissue as biomarkers can be used as a suitable approach to better identify the mechanisms that influence shell and pearl quality and color variations. Lemer et al (2015) and Ky et al (2019) investigated the expression of some candidate genes associated to different mantle morphotypes in P. margaritifera. Using suppressive and subtractive hybridization (SSH) method and RT-qPCR, Lemer et al (2015) identified differentially expressed genes between black and full albino phenotypes of P. margaritifera 10. Comparing the differential expression of a set of genes in black versus orange mutant phenotypes, both in graft tissue and pearl sac, Ky et al (2019) also underlined the existence of differential expression of 4 upon six genes and underlined very different pathways in the orange phenotypes than in the albino ones. Their study also revealed a strong influence of 
the orange phenotype on the color of pearl, leading to lighter colors that may be an interesting source of diversification for jewellery 3.

$P$. persica could be considered as an important model species to investigate the molecular mechanisms involved in phenotypic variation, particularly for color traits, and biomineralization processes of shell and pearl formation in pearl oysters. Owing to the differences observed in the color of mantle tissue and their abundance in two species of Pinctada oysters, the comparison of the mantle gene expression pattern in $P$. persica with those recently reported for $P$. margaritifera 3,10 may help to better understand the molecular mechanisms involved in color differentiation of pearl oysters. Therefore, in this study, the expression of a suite of genes involved in color polymorphism was evaluated in the mantle tissue of two morphotypes of $P$. persica using quantitative reverse transcription PCR (qRT-PCR). In molluscan, temperature is one of the important factors influencing physiological processes 21.22 and a marked effect has been reported on biomineralization 23. Given the potential influence of the environmental factors, i.e., temperature on transcriptome and biomineralization 11.23 , we also investigated the expression of biomineralization genes in warm and cool seasons separately for each morphotype of $P$. persica.

\section{Results:}

Two color phenotypes of $P$. persica i.e., orange and black mantle were observed among the specimens sampled in our study in which the orange phenotype was more abundant than the black one. The results of qRT-PCR revealed that a set of genes were differentially expressed between two phenotypes of $P$. persica. Among the genes involved in the formation of the prismatic layer, the mRNA expression of $A S P, K R M P, S H E M 1 B$ and SHEM5 were significantly higher in the orange phenotype compared to those of black morphotype $(\mathrm{P}<0.05)$. The mRNA expression of $P E R O X$ and $P R I S M$ showed no significant differences between the two investigated phenotypes (Fig. 3). The results also showed that the gene CALM was only expressed in the orange phenotype, while $90 \%$ of individuals with black morphotype showed no CALM mRNA expression.

All the genes related to nacre layer formation (MRNP34, PEARL, SHELL, LINKINE and PIF), showed significantly higher transcript levels in the orange morphotype compared to the black phenotype $(P<0.05)$. The only exception was the PEARL gene in which no transcripts were detected in the individuals with black phenotype, while expression of this gene was detected in $52.3 \%$ of individuals with orange mantle type (Fig. 3 ).

The NACREIN gene which is involved in the formation of both prismatic and nacre layers, also showed significantly higher expression in the mantle of orange morphotype compared to the black morphotype $(\mathrm{P}<0.05$; Fig. 3$)$. Moreover, among the pigmentation related genes, TYR2A showed significantly higher mRNA expression in the orange morphotype compared to the black one $(\mathrm{P}<0.001)$. The $C H I T$ transcripts were not detected in the black morphotype and only $42.8 \%$ individuals of orange phenotype showed CHIT transcripts (Fig. 3). In addition, no significant differences were observed in the expression of the gene SERP between two morphotypes ( $P>0.05$; Fig. 3).

The seasonal variations of the gene transcripts in both phenotypes of $P$. persica are shown in Figs. 4 and 5 . In black mantle phenotype of $P$. persica, ASP, KRMP and SHEM5 transcripts were significantly higher in cool season compared to individuals sampled in warm season, while PIF showed significantly higher mRNA expression in warm season compared to cool season ( $\mathrm{P}<0.05$; Fig. 4). In the orange phenotype, only KRMP and PRISM showed difference in seasonal expression, both with significantly higher expression in cool season rather than warm season $(P<0.05$; Fig. 5).

The PCA analysis revealed that the first cleavage factor is color, with a separation of orange and black groups as shown in PC1 in Fig. 6. The level of variation range in orange group was also more important than that of black phenotype. There was no clear separation between the individuals sampled in two seasons for either color (Fig. 6). 


\section{Discussion:}

In pearl oysters, the color polymorphism of mantle tissue is tightly linked to the color and radiance of shell and pearl 3. Therefore, the study of biomineralization and the genes related to this biological process in mantle tissue of pearl oysters can be used as a suitable approach to better understanding the molecular mechanisms that influence shell and pearl quality and color variations. In this study, we investigated the transcription of a panel of genes encoding proteins involved in biomineralization and pigmentation in black and orange mantle morphotypes of pearl oyster, $P$. persica in both warm and cool seasons using qRT-PCR. Our results showed differential expression of genes between two color morphs of $P$. persica. The set of genes chosen for their involvement in biomineralization of the prismatic and nacre layer, and pigmentation systematically exhibited a significantly higher expression in orange compared to the black phenotypes, suggesting the important role of these genes in color polymorphism in mantle tissue of this species.

Shell coloration has been shown to be related to the original pigments and the chemical interactions between the pigments and the shell matrix in mollusks 24. The pigments may be inserted in the outer or other layers of shells 2425. The molecular pathway of the melanin synthesis has an important contribution to the shell and pearl pigmentation $10 \cdot 26$. According to the results of the present study, the TYR2A gene that is the most important enzyme in the melanin production 27 was higher expressed in the orange phenotype of $P$. persica compared to that of black mantle phenotype. The tyrosinases play diverse roles in mollusk tissues and shells including shell matrix formation 28-31, pigmentation $31-33$, and producing of the periostracum $30,31,34$. It is likely that tyrosinases play a different role in the formation of the shell (calcitic) layer and melanin synthesis between two color morphs of $P$. persica which may result in different amounts of pigments and pigments intensity in different phenotypes 35 . The relationship between gene expression and shell pigmentation was reported in the clam Meretrix meretrix with high expression of the genes in the deeper shell color samples 36. In addition, the relationship between the shell and mantle pigmentation 37 and heritability of shell pigmentation 38 were described in Pacific oyster, Crassostrea gigas 39. Opposite to the findings of Ky et al (2019) and Lemer et al (2015), our results showed significantly differential expression of TYR2A between two morphotypes of $P$. persica. The high expression of $T Y R 2 A$ in orange phenotype may thus be related to the composition of non-functional melanin protein, a hypothesis reported for other genes such as zinc 3,10,40,41.

In addition to tyrosinase, chitin related proteins play prominent roles in the shell formation of bivalve 31 and melanin biosynthesis 10, however the expression of CHIT here was only detected in the orange phenotype, suggesting that an alternative pathway might exist in the black phenotype of P. persica. Both CHIT and PEARL genes which are strongly involved in the formation of nacre in pearl oysters 42-47 and Calmodulin which is prismatic related gene 48 only expressed in orange phenotype of $P$. persica. The calcium binding proteins such as calmodulin, probably play an important role in the regulation of uptake, transport and secretion of calcium and may be essential regulators in the extracellular nacrein construction 49.50. The MRNP34 may be putatively involved in protein/protein interactions, by analogy with other proteins, like calmodulin, which shows two hydrophobic methionine-rich domains that bind to the target protein 51 and involved in nacre formation 52. Therefore, the high expression of these genes in orange morph may confirm their interaction that leads to the enhanced biomineralization and the regulation of microstructure of nacreous layer in this phenotype. Taken together, these results show the important roles of these genes in the calcium metabolism during nacre and prismatic layers formation in orange phenotype of $P$. persica compared to the black one, which should lead to different rate of calcification, calcium content and the aragonite and calcite crystals arrangements in the shell and pearl. It is likely that other genes from different pathways or the genes that their function is still unknown play similar roles in the black morphotype of $P$. persica

Higher expression of PIF in orange phenotype of $P$. persica than that of black phenotypes confirmed the distinct functions of this gene between two color morphs. Pif-177 is an important component of the organic matrix for the 
nacreous layer growth of pearl oysters 53, consists of aragonite-binding domain, chitin-binding domain, and proteinprotein interaction domain 31. It is believed that PIF is involved in the establishment of color in the shell of $P$. margaritifera 10. Lemer et al (2015) argued that the lower expression of PIF in albino than that of black morphotype of $P$. margaritifera, is involved in their different aragonite crystals arrangement that is associated to lower quality in the colorless nacre layer of albino morphotype 10. Therefore, it can be suggested that the higher expression of PIF in orange phenotype of $P$. persica might lead to a higher quality of nacre in this phenotype.

The peroxidases are formed of two clusters that could be classified as melanin biosynthesis group and the shell formation group 31. In this study, we did not observe different expression of PEROX between the two morphotypes, suggesting this gene may not be a key gene of melanin synthesis in $P$. persica.

The transcripts of two genes encoding shematrin proteins (SHEM1B and SHEM5) were remarkably higher expressed in orange phenotype of $P$. persica than those of black mantle phenotype. The shematrin proteins are the most common proteins synthesized in the mantle edge of mollusks 52.54. These proteins are secreted into the prismatic layer of the shell, which is thought to provide a template for calcification and are responsible for the hardness of the shell 54 . These results show the important roles of the shematrin family proteins in calcification of different pearl oyster morphotypes that can cause different hardness in shell and pearl.

Aspein shell matrix protein is known as the most acidic protein in mollusk shell matrix protein that controls the contribution of calcite 55. Higher expression of ASP and KRMP genes that encode proteins involved in calcite layer formation 55,56 in the orange phenotype of $P$. persica might indicate that the calcite layer framework and arrangement differ in the orange compared to the black phenotypes. In P. margaritifera, higher expression of $A S P$ and lower expression of KRMP was observed in the black compared to albino phenotypes 10, while no differences in the expression of $K R M P$ were reported between black and orange mantle of $P$. margaritifera 3 . Such contrasted expression patterns of genes between closely related species suggest the complex and species specific (and possibly evolutionary convergent) genetic processes are involved in the biomineralization in mantle tissue of pearl oysters. Moreover, both $A S P$ and NACREIN play important roles in pearl quality and color phenotypes 57 . It has been reported that the expression of $A S P$ is associated with the pearl sac and quality traits (surface defects, lustre and grade) and color in pearl oysters 58. Since the high expression of NACREIN and ASP was observed in orange phenotype of $P$. persica compared to the black one, we expect to observe different quality and color of pearls between two morphotypes.

Matrix proteins regulate the crystal phase, shape, size and nucleation of $\mathrm{CaCO} 3$ crystals 59 . Altogether, differential expression of the nacre and calcite layer-related genes i.e., ASP, KRMP, SHEM1B, SHEM5, LINKINE, MRNP34, SHELL, PIF, NACREIN and coloration (TYR2A) between two morphotypes of $P$. persica might indicate the different regulation of these genes and its consequences in the rate of calcification, the design of aragonite and calcite crystals in the shell and pearl, the calcium content, the thickness and weight of the prismatic and nacre layers, intensity and pattern of pigmentation, variability of nacre color of shell and pearl color in oysters with different mantle morphotypes in this species. Some studies investigated the gene expression patterns with different phenotypic traits, which showed differential gene expression between different phenotypic groups $3 \cdot 10 \cdot 35 \cdot 36 \cdot 57 \cdot 58 \cdot 60 \cdot 61$. In contrast to our study, the genes encoding the organic matrix proteins produced by the mantle were found to be highly expressed in the black specimens of $P$. margaritifera. It is stated that the pigmentation-related genes i.e., SHEM4, KRMP, MP8, CHIT and SERP are involved in the black eumelanin synthesis 10. Moreover, Lemer et al (2015) reported more expression of genes involved in prismatic layer in the black specimens of $P$. margaritifera and suggested that variation in shell color can primarily occur in the prismatic layer 10 . Therefore, the origin of color can result from multiple interactions between both prismatic and nacre layer, and the pigmentation-related genes, which may be conducted by distinct genes in congeneric, even in closely related species. 
The beauty and lustre of pearls are related to the surface nacreous layer. The nacre layer is made of $\mathrm{CaCO} 3$ aragonite tablets, chitin and matrix proteins 62-64. The accurate and orderly assembly of the crystals and organic matrix not only increases lustre by reflecting light uniformly from the layered compartment 65 , but also strengthens the nacreous layer to provide fracture resistance 66 . The highest levels of matrix protein expression is correlated with the ordered deposition of $\mathrm{CaCO} 359$. According to our result, we might expect a high quality of pearl in orange phenotype of $P$. persica compared to the black one, however experimental approaches are needed to test this hypothesis. Effective selection based on shell and mantle edge color has been already reported in the Pacific oyster 39 . The selection programs can improve traits such as pearl size, color, darkness, surface defects and grade 57.

Our results did not show a high variability in the expression of the gene involved in biomineralization between warm and cool seasons in P. persica. However, the genes ASP, KRMP, SHEM5 in the orange phenotype, and KRMP and PRISM in black phenotype were up-regulated in cool season compared to warm months. This might indicate a decrease in the rate of biomineralization process in summer. It must be noted that the sexual maturation and spawning season of $P$. persica is in warm season and the energy contents of the organism shift to reproductive activities and less energy is spent on other functions. Differential regulation may thus be the result of a direct influence of temperature or other correlated environmental parameter, or of a trade-off with investment in reproductive function, or a combination of both. In fact, the temperature $32{ }^{\circ} \mathrm{C}$ is likely a stressor for this species and energy is spent for compensatory response that can have a negative impact on the mantle gene expression. As $P$. persica was collected from wild environment, other environmental factors also may have affected the gene expression. Previous studies demonstrated the responses of biomineralizationrelated genes to ocean acidification and warming in pearl oysters 11,67-69. Various studies have also shown the effect of temperature on the relative thickness and growth of the shell in oysters 70,71 . Further experiments might be needed to explore the possible influence of global warming on the nature of nacre and the possible evolution of dominant phenotypes, and possibly the potential for pearl production, in natural populations of $P$. persica.

\section{Materials And Methods:}

Thirty-one adult species of $P$. persica from two different color phenotypes of mantle tissue (orange and black; Fig. 1) with 100-170 mm in dorso-ventral length were collected from Larak Island, Persian Gulf $\left(26^{\circ} 53.385^{\prime} \mathrm{N} .5^{\circ}{ }^{\circ} 21.061^{\prime} \mathrm{E}\right.$;

Fig. 2) by scuba diving during warm (September $2019,32^{\circ} \mathrm{C}$ ) and cool (March 2020, $23^{\circ} \mathrm{C}$ ) seasons. The whole sample included six black and twelve orange morphotypes collected in warm season, plus four black and nine orange phenotypes sampled in cool season. The graft part of the mantle tissue was dissected and stored at $-80^{\circ} \mathrm{C}$ until subsequent RNA extraction.

RNA was extracted from $50 \mathrm{mg}$ of the mantle tissue using Trizol® reagent (GeneAll, Korea) in RNase free environment, according to the manufacturer's recommendations with some modifications to improve the purity of RNAs. The tissues were homogenized in liquid nitrogen and treated in Trizol ${ }^{B}$ reagent, accordingly. RNA was precipitated in isopropanol and washed in 75\% ethanol two times and finally eluted in 50 ul DEPC treated water (Biobasic, Canada). RNA was quantified using a Nanodrop spectrophotometer (Thermo Scientific, MA) and the quality of the RNA was checked for degradation using $1 \%(\mathrm{w} / \mathrm{v})$ agarose gel electrophoresis. Total RNA for each individual was then treated with DNase reagent (Thermo Scientific, MA) to cleanup potential DNA residuals. Afterwards, cDNA was synthesized using $1 \mu \mathrm{g}$ of total RNA as a template, and a cDNA synthesis kit (SMOBio, Taiwan) containing $1 \mu \mathrm{l}$ T primer and $0.2 \mu \mathrm{l}$ random primers, following the manufacturer's instructions.

In order to identify the relative gene expression profiles of black and orange mantle tissues, 16 candidate genes were targeted based on their functions (Table 1). The selected genes were divided into 5 categories (defined based on Lemer et al (2015) and Ky et al (2019) studies) as follow; 1] genes involved in the formation of the prismatic layer: ASP, KRMP, Peroxidas, Shematrin1, Prismalin, Shematrin 5 and Calmodulin 10,52:54,55,72-74; 2] the nacre layer-related genes 
including MRNP34, Perline, SHELL, Linkine and Pif-177 10,47.52,53,72,75; 3] the gene Nacrein involved in the formation of both prismatic and nacre layers 49,52,54; 4] the genes involved in the color of the shell, Tyrosinase 2 and Chitin 10 and 5] a gene indirectly involved in biomineralization process, SERP 3.

For normalization of the target genes, various housekeeping genes including 18S ribosomal RNA (18SrRNA), Beta actin $(\beta$-actin) and Elongation factor 1 alpha (EF-a1) were initially considered as internal reference genes. The18S gene was shown as the most stable reference gene for qPCR in P. persica (supplementary Fig. 1) and was chosen for normalizing the target genes owing to its constitutive expression patterns in mantle tissue. The primers were designed using the Primer3 software (https://bioinfo.ut.ee/primer3-0.4.0; Primer size: 19-23, Tm: 57-62, Product size ranges: 100-170; Table 1). The specificity of the designed primers was checked by primer blast (https://www.ncbi.nlm.nih.gov/tools/primer-blast/). In addition, the primers for genes CHIT, KRMP and SERP were adopted from pervious studies (Table 1). Then all the primer pairs (Table 1) were checked on synthesized cDNA from $P$. persica using normal PCR to ensure their amplification success and consistency.

qRT-PCR amplifications were carried out on a StepOne Real-Time PCR (ThermoFisher Scientific, MA) in final volume of $10 \mu \mathrm{l}$ included $1 \mu \mathrm{l} \mathrm{cDNA}, 5 \mu \mathrm{l}$ of $2 X$ SYBR green mix (Ampliqon, Denmark) and $0.25 \mu \mathrm{M}$ of each primer (listed in Table 1). The reaction started with initial denaturation at $94^{\circ} \mathrm{C}$ for $120 \mathrm{~s}$ and then 40 cycles of $94^{\circ} \mathrm{C}$ for $30 \mathrm{~s}, 58^{\circ} \mathrm{C}$ for 30 $\mathrm{s}$ and $72^{\circ} \mathrm{C}$ for $20 \mathrm{~s}$ followed by gradual thermo scanning ( 0.3 degree per step) for melting curve analysis. The RT-qPCR reactions were run in duplicate for each sample. The $\mathrm{Ct}$ values were exported after baseline normalization using the Real-Time PCR StepOne Software (ThermoFisher Scientific, MA). PCR efficiencies for each gene were calculated using LinRegPCR 76. The relative expression of target genes was calculated by $2^{-\Delta \Delta C T}$ method 77 , and then were log2transformed.

The log2-transformed gene expression data were tested for normality using Shapiro-Wilk test and homogeneity of variance using Leven's test to meet T-test assumptions. T-student test were used to check the source of significant difference in gene expression between the two morphotypes and two different seasons. Statistical analyses were conducted with SigmaPlot-v11 (version 11).

The principal components analysis (PCA) was carried out in order to transform the variables and indicated the ordination of target genes against independent variables (color and season) using the fviz_pca function of the factoextra R package 78 . This function provided 95\% confidence ellipses for groups within each data set 79,80. 
Table 1

Details of the candidate genes and the primer pairs used for gene expression analysis in Pinctada persica in this study.

\begin{tabular}{|c|c|c|c|c|c|}
\hline $\begin{array}{l}\text { Gene } \\
\text { name }\end{array}$ & $\begin{array}{l}\text { Gene } \\
\text { description }\end{array}$ & Function & Seq $\left(5^{\prime}-3^{\prime}\right)$ & $\begin{array}{l}\text { Amplicon } \\
\text { Length } \\
\text { (bp) }\end{array}$ & $\begin{array}{l}\text { Accession } \\
\text { number and } \\
\text { citation }\end{array}$ \\
\hline \multirow[t]{2}{*}{$\mathrm{ASP}^{1}$} & \multirow{2}{*}{$\begin{array}{l}\text { Aspein shell } \\
\text { matrix protein }\end{array}$} & \multirow{2}{*}{$\begin{array}{l}\text { Prismatic } \\
\text { formation }\end{array}$} & TCACAATGAAGGGGATAGCC & \multirow[t]{2}{*}{110} & \multirow[t]{2}{*}{ AB685319.1 } \\
\hline & & & TACGCCTGATGACCCTAGTT & & \\
\hline \multirow[t]{2}{*}{ CALM } & \multirow[t]{2}{*}{ Calmodulin } & \multirow{2}{*}{$\begin{array}{l}\text { Prismatic } \\
\text { formation }\end{array}$} & ATAACAACCAAGGAGCTGGGT & \multirow[t]{2}{*}{106} & \multirow[t]{2}{*}{ AY341376.1 } \\
\hline & & & TTCCGTTTCCATCAGCGTCTA & & \\
\hline \multirow[t]{2}{*}{$\mathrm{CHIT}^{1}$} & \multirow[t]{2}{*}{ Chitin synthase } & \multirow[t]{2}{*}{ Coloration } & СCTTGTGGGATGTCTCCTGAA & \multirow[t]{2}{*}{103} & \multirow[t]{2}{*}{ AB290881.1 } \\
\hline & & & GCACTAGCTTGCAAAATCGGA & & \\
\hline \multirow[t]{2}{*}{$\mathrm{KRMP}^{1,2}$} & \multirow{2}{*}{$\begin{array}{l}\text { Lysine (K)-rich } \\
\text { mantle protein }\end{array}$} & \multirow{2}{*}{$\begin{array}{l}\text { Prismatic } \\
\text { formation }\end{array}$} & GCCTTCACCACAGAAGGAAG & \multirow[t]{2}{*}{147} & \multirow{2}{*}{$\begin{array}{l}\text { Ky et al } \\
(2018)\end{array}$} \\
\hline & & & GCCGAATTTCTTCAGACACC & & \\
\hline \multirow[t]{2}{*}{ LINKINE } & \multirow[t]{2}{*}{ Linkine } & \multirow[t]{2}{*}{ Nacre formation } & AGTTGCCAACAGAGTTATACTA & \multirow[t]{2}{*}{104} & \multirow[t]{2}{*}{ EF183520.1 } \\
\hline & & & TCCACAAAGTTTAATACGAAAA & & \\
\hline \multirow[t]{2}{*}{ MRNP34 } & \multirow{2}{*}{$\begin{array}{l}\text { Methionine-rich } \\
\text { nacre protein } \\
34\end{array}$} & \multirow[t]{2}{*}{ Nacre formation } & GGATACTGTGCTTAGCCGTT & \multirow[t]{2}{*}{156} & \multirow[t]{2}{*}{ HQ625028.1 } \\
\hline & & & TAGACTTTTGTGGCACTGCA & & \\
\hline \multirow[t]{2}{*}{ NACREIN } & \multirow[t]{2}{*}{ Nacrein B4 } & Prismatic and & CAATGAGACCGTCCTTTGGG & 141 & HQ654772.1 \\
\hline & & & TTTCTCTGTGTGGGACGTCT & & \\
\hline PEARL $^{1}$ & Perline matrix & Nacre formation & TAACCATGACGTGCACACTT & 132 & DQ665305.3 \\
\hline & & & CTATGTCATACGGCAGCCAA & & \\
\hline PEROX ${ }^{1}$ & Peroxidas & Prismatic & GGAAGGAGGGCATTTGTCTT & 135 & HE610394.1 \\
\hline & & & CATCTCTGTCATGCCTCCAG & & \\
\hline $\mathrm{PIF}^{1}$ & Pif177-like & Nacre formation & AGATTGAGGGCATAGCATGG & 137 & HE610401.1 \\
\hline & promiction & & TGAGGCCGACTTTCTTGGC & & \\
\hline PRISM $^{1}$ & $\begin{array}{l}\text { Prismalin } 14 \\
\text { (Prism }\end{array}$ & $\begin{array}{l}\text { Prismatic } \\
\text { formation }\end{array}$ & AGGATTCTACAGATTTGGCGA & 116 & HE610393.1 \\
\hline & $\begin{array}{l}\text { uncharacterized } \\
\text { shell protein) }\end{array}$ & & TAACAATTGGAGAGGCACGT & & \\
\hline SERP $^{1,2}$ & Serine protease & Indirect role in & AGGTGTGTACCATTCTTCTACGG & 1007 & Lemer et al \\
\hline & & & GCAAACATCTССТССАТСТСC & & \\
\hline SHELL $^{1}$ & Nacre & Nacre formation & TACATGCCCGACAATTGGTT & 100 & HE610404.1 \\
\hline & shell protein 6 & & TTCCTTGGTTTCTTCCGCTT & & \\
\hline SHEM1B $^{1}$ & Shematrin 1 & $\begin{array}{l}\text { Prismatic } \\
\text { formation }\end{array}$ & GTGTGTCCCAGTCTCTTTCC & 163 & KC505165.1 \\
\hline nese & are similar to & used in Lemer & (2015). & & \\
\hline
\end{tabular}




\begin{tabular}{|c|c|c|c|c|c|}
\hline $\begin{array}{l}\text { Gene } \\
\text { name }\end{array}$ & $\begin{array}{l}\text { Gene } \\
\text { description }\end{array}$ & Function & Seq $\left(5^{\prime}-3^{\prime}\right)$ & $\begin{array}{l}\text { Amplicon } \\
\text { Length } \\
\text { (bp) }\end{array}$ & $\begin{array}{l}\text { Accession } \\
\text { number and } \\
\text { citation }\end{array}$ \\
\hline & \multicolumn{5}{|c|}{ CCACCTCCGTAAATACCACC } \\
\hline \multirow[t]{2}{*}{ SHEM5 } & \multirow[t]{2}{*}{ Shematrin 5} & \multirow{2}{*}{$\begin{array}{l}\text { Prismatic } \\
\text { formation }\end{array}$} & TTTGTGTCAGGGTTGTGGAG & \multirow[t]{2}{*}{156} & \multirow[t]{2}{*}{ HE610376.1 } \\
\hline & & & TGGCTATCATCATCGTTGCA & & \\
\hline \multirow[t]{2}{*}{ TYR2A ${ }^{1,2}$} & \multirow[t]{2}{*}{ Tyrosinase 2} & \multirow[t]{2}{*}{ Coloration } & GCGGCTCTACTGTCAAATGG & \multirow[t]{2}{*}{106} & \multirow{2}{*}{$\begin{array}{l}\text { Lemer et al } \\
\text { (2015) }\end{array}$} \\
\hline & & & CTGGACCTTTCAGGGACTGG & & \\
\hline \multirow{2}{*}{$\begin{array}{l}18 S \\
\text { rRNA }^{1}\end{array}$} & \multirow{2}{*}{$\begin{array}{l}\text { 18S ribosomal } \\
\text { RNA }\end{array}$} & \multirow[t]{2}{*}{ Reference gene } & TTAGTTGGTGGAGCGATTT & \multirow[t]{2}{*}{365} & \multirow{2}{*}{$\begin{array}{l}\text { Larsen et al } \\
(2005)\end{array}$} \\
\hline & & & TAGCGACGGGCGGTGTG & & \\
\hline \multirow[t]{2}{*}{$E F-1 a^{1}$} & \multirow{2}{*}{$\begin{array}{l}\text { Elongation } \\
\text { facto-1 alpha }\end{array}$} & \multirow[t]{2}{*}{ Reference gene } & CCACGAGTCCTTACCAGAGG & \multirow[t]{2}{*}{115} & \multirow{2}{*}{$\begin{array}{l}\text { Le luyer et al } \\
\text { (2019) }\end{array}$} \\
\hline & & & TGGATCACTTTTGCTGTCTCC & & \\
\hline \multirow[t]{2}{*}{$\beta-A C T$} & \multirow[t]{2}{*}{ Beta actin } & \multirow[t]{2}{*}{ Reference gene } & ССТСАСССТСААGТАССССАТ & \multirow[t]{2}{*}{153} & \multirow{2}{*}{$\begin{array}{l}\text { XM- } \\
011446513.3\end{array}$} \\
\hline & & & TTGGCCTTTGGGTTGAGTG & & \\
\hline \multicolumn{6}{|c|}{${ }^{1}$ These genes are similar to those used in Lemer et al (2015). } \\
\hline
\end{tabular}

\section{Conclusion:}

The goal of present study was to compare the expression of genes involved in biomineralization and pigmentation in the orange and black phenotypes of $P$. persica. Our results showed different expression profiles of genes between these two color morphs. Genes involved in biomineralization and pigmentation were significantly higher expressed in the orange phenotype of $P$. persica that is more dominant morphotype in Persian Gulf. Our results were in contrast with those obtained in the closely related species, P. margaritifera with higher expression of biomineralization and pigmentation genes in the black dominant morphotype. It can be stated that the regulation of genes involved in the color polymorphism of mantle tissue in pearl oysters might have an important role in the quality of the pearl product that requires further studies.

\section{Declarations}

\section{Acknowledgments:}

We would especially like to thank Mr. Kaveh Khosraviani (CellKGP Company, Genetic and Biotechnology laboratory, Karaj, Iran) for providing valuable guidance towards improving the manuscript. We are also grateful to Persian Gulf Biotechnology Park (PGBP) for their generous support to develop this study. The authors also would like to acknowledge the support provided by Mr. Eghbal Zobairi for the map preparation. All individual rights, animal rights and scientific ethics have been observed in this study.

\section{Funding:}

This study was financially supported by Persian Gulf Biotechnology Park (PGBP), Qeshm Island, Iran. 


\section{Authors' contribution:}

MSR supervised the study and conducted the sampling. MSR and AF designed the experiments. FP and MSR carried out the molecular genetic studies and experiments in the laboratory and wrote the manuscript. AA, MSR, FP and SAH analyzed the data and contributed to reviewing the manuscript. All authors read and approved the final manuscript.

\section{Competing interests:}

No potential conflict of interest was reported by the authors.

\section{References}

1 Strack, E. in The pearl oyster (eds Paul Southgate \& John Lucas) Ch. 1, 1-35 (Elsevier, 2008).

2 Fougerouse, A., Rousseau, M. \& Lucas, J. S. in The pearl oyster (eds Southgate P.C. \& Lucas J.S.) 77-102 (Elsevier, 2008).

3 Ky, C.-L., Blay, C., Broustal, F., Koua, M. S. \& Planes, S. Relationship of the orange tissue morphotype with shell and pearl colouration in the mollusc Pinctada margaritifera. Scientific reports 9, 1-9 (2019).

4 Shirai, S. \& Nakamura, S. Pearls and pearl oysters of the world. (Marine Planning, 1994).

5 Hwang, J. J. \& Okutani, T. Taxonomy and distribution of the genera Pteria and Pinctada (Bivalvia: Pteriidae) in Taiwan. Journal of the Fisheries Society of Taiwan 30, 199-216 (2003).

6 Wada, K. T. \& Tëmkin, I. in The pearl oyster (eds P C Southgate \& J S Lucas) 37-75 (Elsevier, 2008).

7 Parvizi, F., Monsefi, M., Noori, A. \& Ranjbar, M. S. Mantle histology and histochemistry of three pearl oysters: Pinctada persica, Pinctada radiata and Pteria penguin. Molluscan Research 38, 11-20 (2018).

8 Ranjbar, M. S. et al. Rising the Persian Gulf black-lip pearl oyster to the species level: fragmented habitat and chaotic genetic patchiness in Pinctada persica. Evolutionary Biology 43, 131-143 (2016).

9 Ky, C. L., Nakasai, S., Pommier, S., Sham Koua, M. \& Devaux, D. The Mendelian inheritance of rare flesh and shell colour variants in the black-lipped pearl oyster (Pinctada margaritifera). Animal genetics 47, 610-614 (2016).

10 Lemer, S., Saulnier, D., Gueguen, Y. \& Planes, S. Identification of genes associated with shell color in the blacklipped pearl oyster, Pinctada margaritifera. BMC genomics 16, 1-14 (2015).

$11 \mathrm{Li}, \mathrm{S}$. et al. Transcriptome and biomineralization responses of the pearl oyster Pinctada fucata to elevated CO 2 and temperature. Scientific reports 6, 1-10 (2016).

$12 \mathrm{Li}, \mathrm{S}$. et al. Interactive effects of seawater acidification and elevated temperature on the transcriptome and biomineralization in the pearl oyster Pinctada fucata. Environmental Science \& Technology 50, 1157-1165 (2016).

13 Shi, Y. et al. Characterization of the pearl oyster (Pinctada martensii) mantle transcriptome unravels biomineralization genes. Marine biotechnology 15, 175-187 (2013).

14 Freer, A., Bridgett, S., Jiang, J. \& Cusack, M. Biomineral proteins from Mytilus edulis mantle tissue transcriptome. Marine biotechnology 16, 34-45 (2014). 
15 Sun, X., Yang, A., Wu, B., Zhou, L. \& Liu, Z. Characterization of the mantle transcriptome of yesso scallop (Patinopecten yessoensis): identification of genes potentially involved in biomineralization and pigmentation. PloS one 10, e0122967 (2015).

16 Wang, X., Liu, Z. \& Wu, W. Transcriptome analysis of the freshwater pearl mussel (Cristaria plicata) mantle unravels genes involved in the formation of shell and pearl. Molecular genetics and genomics 292, 343-352 (2017).

17 Gardner, L. D., Mills, D., Wiegand, A., Leavesley, D. \& Elizur, A. Spatial analysis of biomineralization associated gene expression from the mantle organ of the pearl oyster Pinctada maxima. BMC genomics 12, 1-16 (2011).

18 Joubert, C. et al. Transcriptome and proteome analysis of Pinctada margaritifera calcifying mantle and shell: focus on biomineralization. BMC genomics 11, 1-13 (2010).

19 Wada, K. White coloration of the prismatic layer in inbred Japanese pearl oyster, Pinctada fucata. Bulletin of National Research Institute of Aquaculture (Japan) (1983).

20 Clark, M. S. et al. Insights into shell deposition in the Antarctic bivalve Laternula elliptica: gene discovery in the mantle transcriptome using 454 pyrosequencing. Bmc Genomics 11, 1-14 (2010).

21 Taylor, A. \& Venn, T. Seasonal variation in weight and biochemical composition of the tissues of the queen scallop, Chlamys opercularis, from the Clyde Sea area. journal of the Marine Biological Association of the United Kingdom 59, 605-621 (1979).

22 Park, M. S. Reproductive cycle and biochemical composition of the ark shell Scapharca broughtonii (Schrenck) in a southern coastal bay of Korea. Journal of Shellfish Research 20, 177-184 (2001).

23 Yao, C.-L. \& Somero, G. N. The impact of ocean warming on marine organisms. Chinese Science Bulletin 59, 468479 (2014).

24 Williams, S. T. Molluscan shell colour. Biological Reviews 92, 1039-1058 (2017).

25 Budd, A., McDougall, C., Green, K. \& Degnan, B. M. Control of shell pigmentation by secretory tubules in the abalone mantle. Frontiers in Zoology 11, 1-9 (2014).

26 Palumbo, A. Melanogenesis in the ink gland of Sepia officinalis. Pigment Cell Research 16, 517-522 (2003).

27 Ding, J. et al. Identification of shell-color-related microRNAs in the Manila clam Ruditapes philippinarum using high-throughput sequencing of small RNA transcriptomes. Scientific reports 11, 1-8 (2021).

28 Degens, E. T., Spencer, D. W. \& Parker, R. H. Paleobiochemistry of molluscan shell proteins. Comparative Biochemistry and Physiology 20, 553-579 (1967).

29 Gordon, J. \& Carriker, M. Sclerotized protein in the shell matrix of a bivalve mollusc. Marine Biology 57, 251-260 (1980).

30 Waite, J. in The Mollusca (eds A S M Saleudin \& K M Wilbur) Ch. 11, 467-504 (Academic, 1983).

31 Feng, D., Li, Q., Yu, H., Kong, L. \& Du, S. Identification of conserved proteins from diverse shell matrix proteome in Crassostrea gigas: characterization of genetic bases regulating shell formation. Scientific reports 7, 1-12 (2017). 
32 Nagai, K., Yano, M., Morimoto, K. \& Miyamoto, H. Tyrosinase localization in mollusc shells. Comparative Biochemistry and Physiology Part B: Biochemistry and Molecular Biology 146, 207-214 (2007).

33 Takgi, R. \& Miyashita, T. A cDNA cloning of a novel alpha-class tyrosinase of Pinctada fucata: its expression analysis and characterization of the expressed protein. Enzyme research 2014 (2014).

34 Waite, J. H. \& Wilbur, K. M. Phenoloxidase in the periostracum of the marine bivalve Modiolus demissus Dillwyn. Journal of Experimental Zoology 195, 359-367 (1976).

35 Stenger, P.-L. et al. Molecular Pathways and Pigments Underlying the Colors of the Pearl Oyster Pinctada margaritifera var. cumingii (Linnaeus 1758). Genes 12, 421 (2021).

36 Yue, X., Nie, Q., Xiao, G. \& Liu, B. Transcriptome analysis of shell color-related genes in the clam Meretrix meretrix. Marine Biotechnology 17, 364-374 (2015).

37 Brake, J., Evans, F. \& Langdon, C. Evidence for genetic control of pigmentation of shell and mantle edge in selected families of Pacific oysters, Crassostrea gigas. Aquaculture 229, 89-98 (2004).

38 Evans, S., Camara, M. D. \& Langdon, C. J. Heritability of shell pigmentation in the Pacific oyster, Crassostrea gigas. Aquaculture 286, 211-216 (2009).

39 Kang, J.-H. et al. Characterizations of shell and mantle edge pigmentation of a Pacific oyster, Crassostrea gigas, in Korean Peninsula. Asian-Australasian journal of animal sciences 26, 1659 (2013).

40 King, R. A. \& Summers, C. Albinism. Dermatol Clin 6, 217-228 (1988).

41 Oetting, W. S. \& King, R. A. Molecular basis of albinism: mutations and polymorphisms of pigmentation genes associated with albinism. Human mutation 13, 99-115 (1999).

42 Suzuki, M. \& Nagasawa, H. The structure-function relationship analysis of Prismalin-14 from the prismatic layer of the Japanese pearl oyster, Pinctada fucata. The FEBS journal 274, 5158-5166 (2007).

43 Miyashita, T. et al. Complementary DNA cloning and characterization of pearlin, a new class of matrix protein in the nacreous layer of oyster pearls. Marine Biotechnology 2, 409-418 (2000).

44 Yan, Z. et al. N40, a novel nonacidic matrix protein from pearl oyster nacre, facilitates nucleation of aragonite in vitro. Biomacromolecules 8, 3597-3601 (2007).

45 Kono, M., Hayashi, N. \& Samata, T. Molecular mechanism of the nacreous layer formation in Pinctada maxima. Biochemical and biophysical research communications 269, 213-218 (2000).

46 Montagnani, C. et al. Pmarg-pearlin is a matrix protein involved in nacre framework formation in the pearl oyster Pinctada margaritifera. Chembiochem 12, 2033-2043 (2011).

47 Samata, T. et al. A new matrix protein family related to the nacreous layer formation of Pinctada fucata. Febs Letters 462, 225-229 (1999).

48 Marie, B. et al. Different secretory repertoires control the biomineralization processes of prism and nacre deposition of the pearl oyster shell. Proceedings of the National Academy of Sciences 109, 20986-20991 (2012). 
49 Miyamoto, H. et al. A carbonic anhydrase from the nacreous layer in oyster pearls. Proceedings of the National Academy of Sciences 93, 9657-9660 (1996).

50 Huang, J., Zhang, C., Ma, Z., Xie, L. \& Zhang, R. A novel extracellular EF-hand protein involved in the shell formation of pearl oyster. Biochimica et Biophysica Acta (BBA)-General Subjects 1770, 1037-1044 (2007).

51 Siivari, K., Zhang, M., Palmer, A. G. \& Vogel, H. J. NMR studies of the methionine methyl groups in calmodulin. FEBS letters 366, 104-108 (1995).

52 Marie, B. et al. Characterization of MRNP34, a novel methionine-rich nacre protein from the pearl oysters. Amino acids 42, 2009-2017 (2012).

53 Suzuki, M. et al. An acidic matrix protein, Pif, is a key macromolecule for nacre formation. Science 325, 13881390 (2009).

54 Yano, M., Nagai, K., Morimoto, K. \& Miyamoto, H. Shematrin: a family of glycine-rich structural proteins in the shell of the pearl oyster Pinctada fucata. Comparative Biochemistry and Physiology Part B: Biochemistry and Molecular Biology 144, 254-262 (2006).

55 Tsukamoto, D., Sarashina, I. \& Endo, K. Structure and expression of an unusually acidic matrix protein of pearl oyster shells. Biochemical and biophysical research communications 320, 1175-1180 (2004).

56 Zhang, C., Xie, L., Huang, J., Chen, L. \& Zhang, R. A novel putative tyrosinase involved in periostracum formation from the pearl oyster (Pinctada fucata). Biochemical and biophysical research communications 342, 632-639 (2006).

57 Blay, C., Planes, S. \& Ky, C.-L. Crossing phenotype heritability and candidate gene expression in grafted blacklipped pearl oyster Pinctada margaritifera, an animal chimera. Journal of Heredity 109, 510-519 (2018).

58 Blay, C., Planes, S. \& Chin-Long, K. Donor and recipient contribution to phenotypic traits and the expression of biomineralisation genes in the pearl oyster model Pinctada margaritifera. Scientific reports 7, 1-12 (2017).

59 Liu, X. et al. The role of matrix proteins in the control of nacreous layer deposition during pearl formation. Proceedings of the Royal Society B: Biological Sciences 279, 1000-1007 (2012).

60 Shi, Y. \& He, M. Differential gene expression identified by RNA-Seq and qPCR in two sizes of pearl oyster (Pinctada fucata). Gene 538, 313-322 (2014).

61 Ky, C.-L., Quillien, V., Broustal, F., Soyez, C. \& Devaux, D. Phenome of pearl quality traits in the mollusc transplant model Pinctada margaritifera. Scientific reports 8, 1-11 (2018).

62 Grégoire, C. Topography of the organic components in mother-of-pearl. The Journal of Cell Biology 3, 797-808 (1957).

63 Wise, S. W. Microstructure and mode of formation of nacre (mother-of-pearl) in pelecypods, gastropods, and cephalopods. Eclogae geol Helve 63, 775-797 (1970).

64 Watabe, N. Studies on shell formation: XI. Crystal-matrix relationships in the inner layers of mollusk shells. Journal of ultrastructure research 12, 351-370 (1965).

65 Mann, S. Biomineralization: principles and concepts in bioinorganic materials chemistry. Vol. 5 (Oxford University Press on Demand, 2001).

Page 13/19 
66 Smith, B. L. et al. Molecular mechanistic origin of the toughness of natural adhesives, fibres and composites. Nature 399, 761-763 (1999).

67 Liu, W., Huang, X., Lin, J. \& He, M. Seawater acidification and elevated temperature affect gene expression patterns of the pearl oyster Pinctada fucata. PLoS One 7, e33679 (2012).

68 Moya, A. et al. Whole transcriptome analysis of the coral Acropora millepora reveals complex responses to CO2driven acidification during the initiation of calcification. Molecular ecology 21, 2440-2454 (2012).

69 Joubert, C. et al. Temperature and food influence shell growth and mantle gene expression of shell matrix proteins in the pearl oyster Pinctada margaritifera. PloS one 9, e103944 (2014).

70 Pouvreau, S. \& Prasil, V. Growth of the black-lip pearl oyster, Pinctada margaritifera, at nine culture sites of French Polynesia: synthesis of several sampling designs conducted between 1994 and 1999. Aquatic Living Resources 14, 155163 (2001).

71 Kanazawa, T. \& Sato, S. i. Environmental and physiological controls on shell microgrowth pattern of Ruditapes philippinarum (Bivalvia: Veneridae) from Japan. Journal of Molluscan Studies 74, 89-95 (2008).

72 Le Luyer, J. et al. Whole transcriptome sequencing and biomineralization gene architecture associated with cultured pearl quality traits in the pearl oyster, Pinctada margaritifera. BMC genomics 20, 1-11 (2019).

73 Suzuki, M. et al. Characterization of Prismalin-14, a novel matrix protein from the prismatic layer of the Japanese pearl oyster (Pinctada fucata). Biochemical Journal 382, 205-213 (2004).

74 Zhang, C., Xie, L., Huang, J., Liu, X. \& Zhang, R. A novel matrix protein family participating in the prismatic layer framework formation of pearl oyster, Pinctada fucata. Biochemical and biophysical research communications 344, 735740 (2006).

75 Gervis, M. H. \& Sims, N. A. The biology and culture of pearl oysters (Bivalvia pteriidae). Vol. 2149 (WorldFish, 1992).

76 Ramakers, C., Ruijter, J. M., Lekanne Deprez, R. H. \& Moorman, A. F. M. Assumption-free analysis of quantitative real-time polymerase chain reaction (PCR) data. Neuroscience Letters 339, 62-66 (2003).

77 Livak, K. J. \& Schmittgen, T. D. Analysis of relative gene expression data using real-time quantitative PCR and the 2- $\Delta \Delta$ CT method. methods 25, 402-408 (2001).

78 Kassambara, A. \& Mundt, F. Factoextra: extract and visualize the results of multivariate data analyses. $R$ package version 1, 337-354 (2017).

79 Houde, A. L. S. et al. Salmonid gene expression biomarkers indicative of physiological responses to changes in salinity and temperature, but not dissolved oxygen. Journal of Experimental Biology 222 (2019).

80 Akbarzadeh, A., Houde, A. L. S., Sutherland, B. J., Günther, O. P. \& Miller, K. M. Identification of hypoxia-specific biomarkers in salmonids using RNA-sequencing and validation using high-throughput qPCR. G3: Genes, Genomes, Genetics 10, 3321-3336 (2020).

\section{Figures}



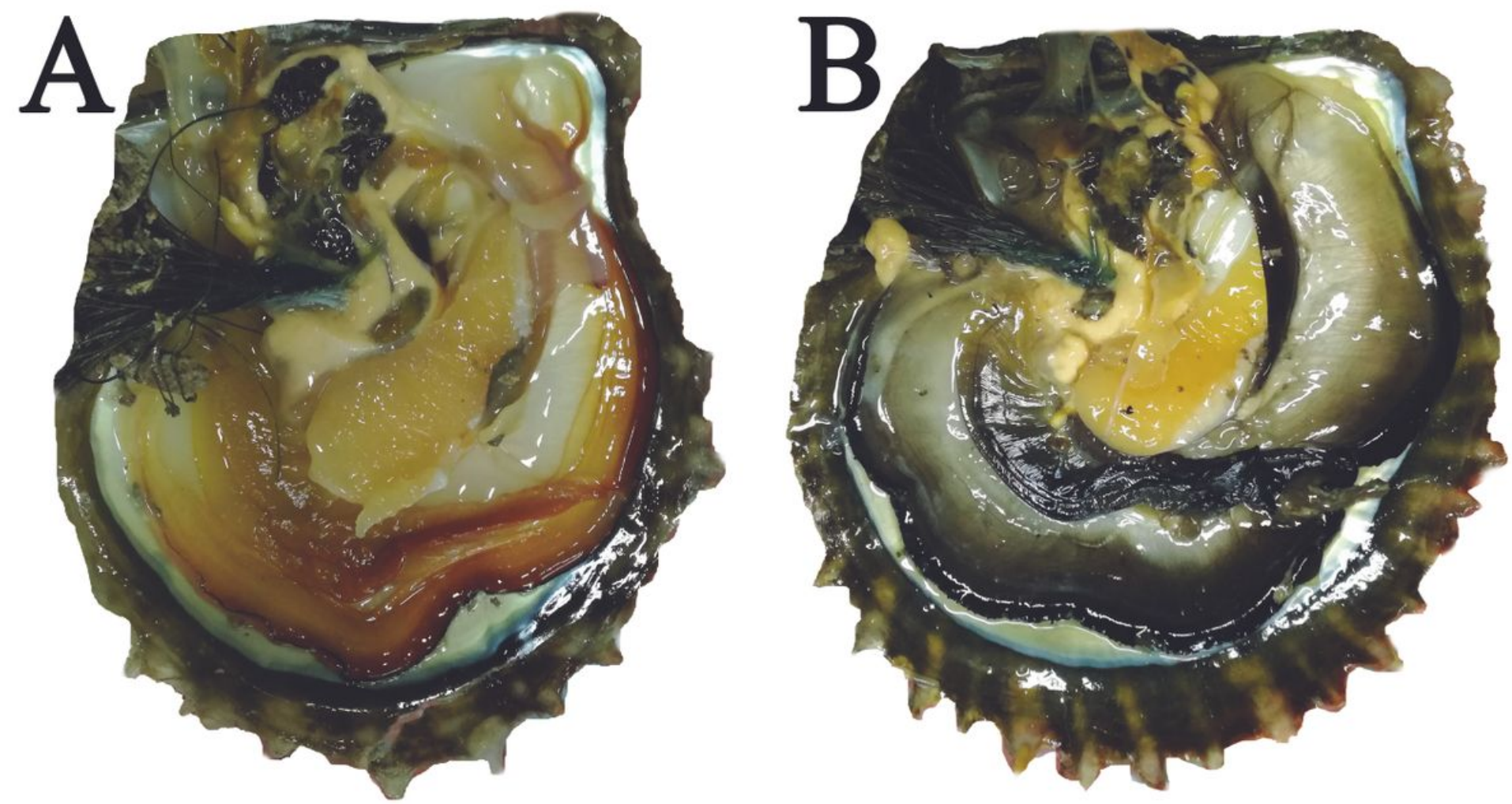

Figure 1

Two common morphotypes of Pinctada persica found in Persian Gulf which were investigated in this study. A: Orange morphotype, B: Black morphotype.

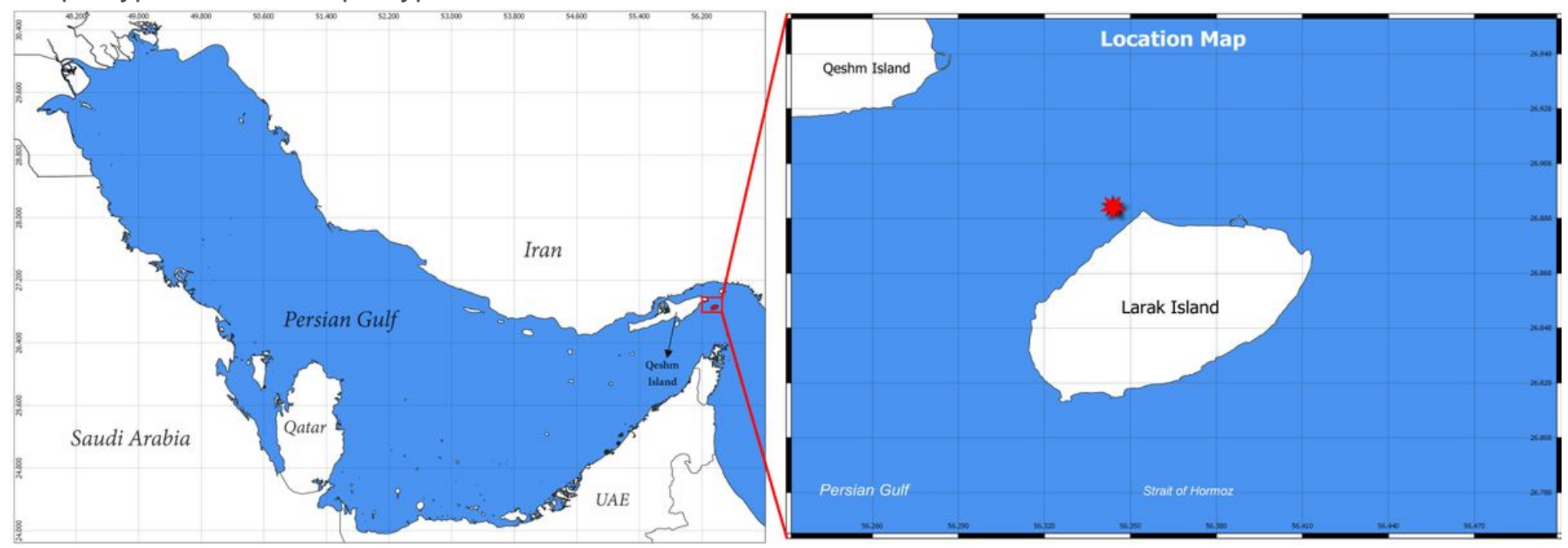

Figure 2

Sampling site on Larak Island, Persian Gulf, Iran. Credit: Eghbal Zobeiri. 

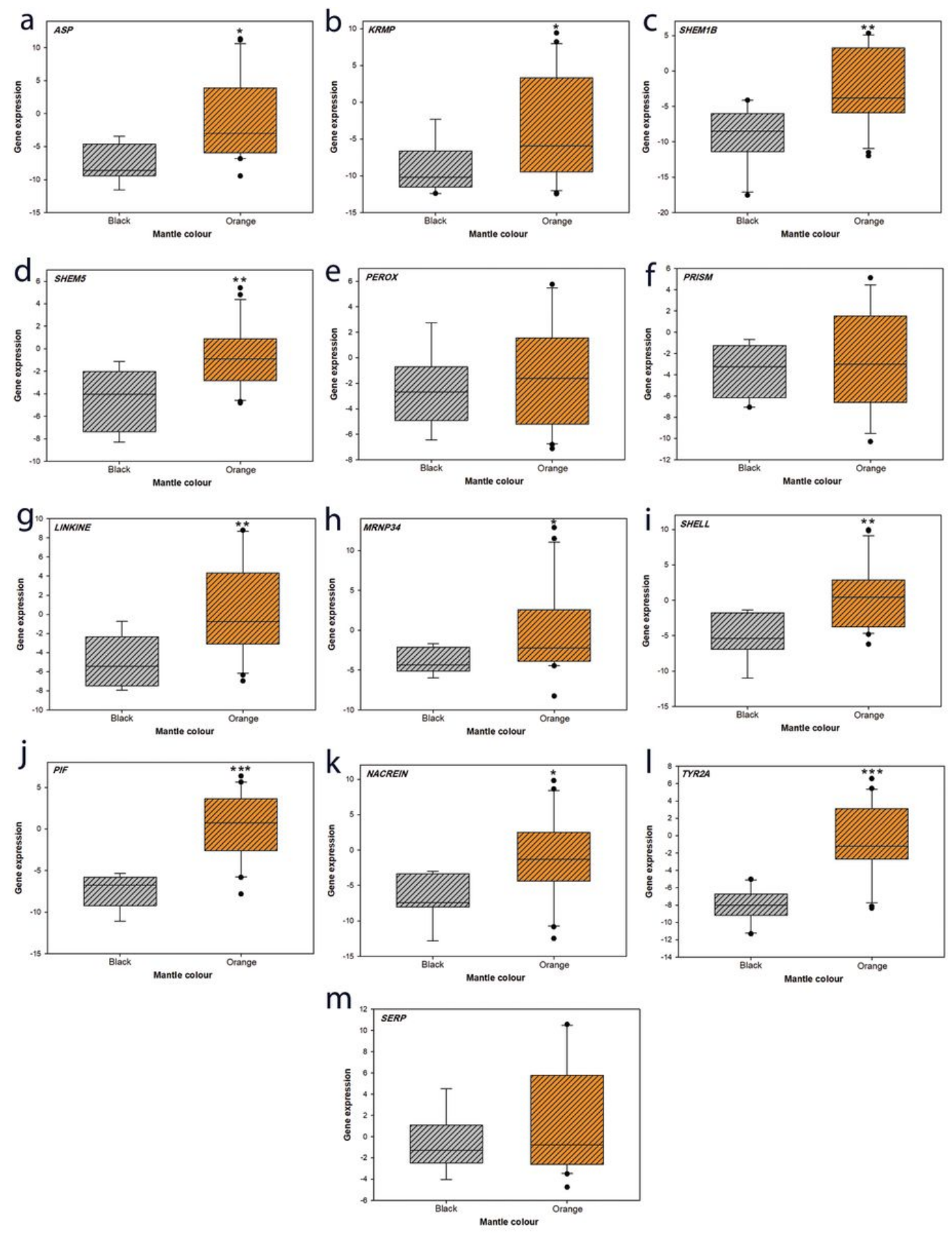

Figure 3

The box plots of the expression of genes involved in biomineralization process in orange and black phenotypes of the pearl oyster Pinctada persica. Grey bars represent data for the black phenotype and orange bars represent data for the orange phenotype. $Y$ axis is in the logarithmic scale (gene expression). Error bars indicate standard deviations. The genes CALM, PEARL and CHIT were only expressed in the orange phenotype. Statistical differences between the phenotypes are indicated by asterisks: *:P<0.05, **:P<0.01, ***:P<0.001. 

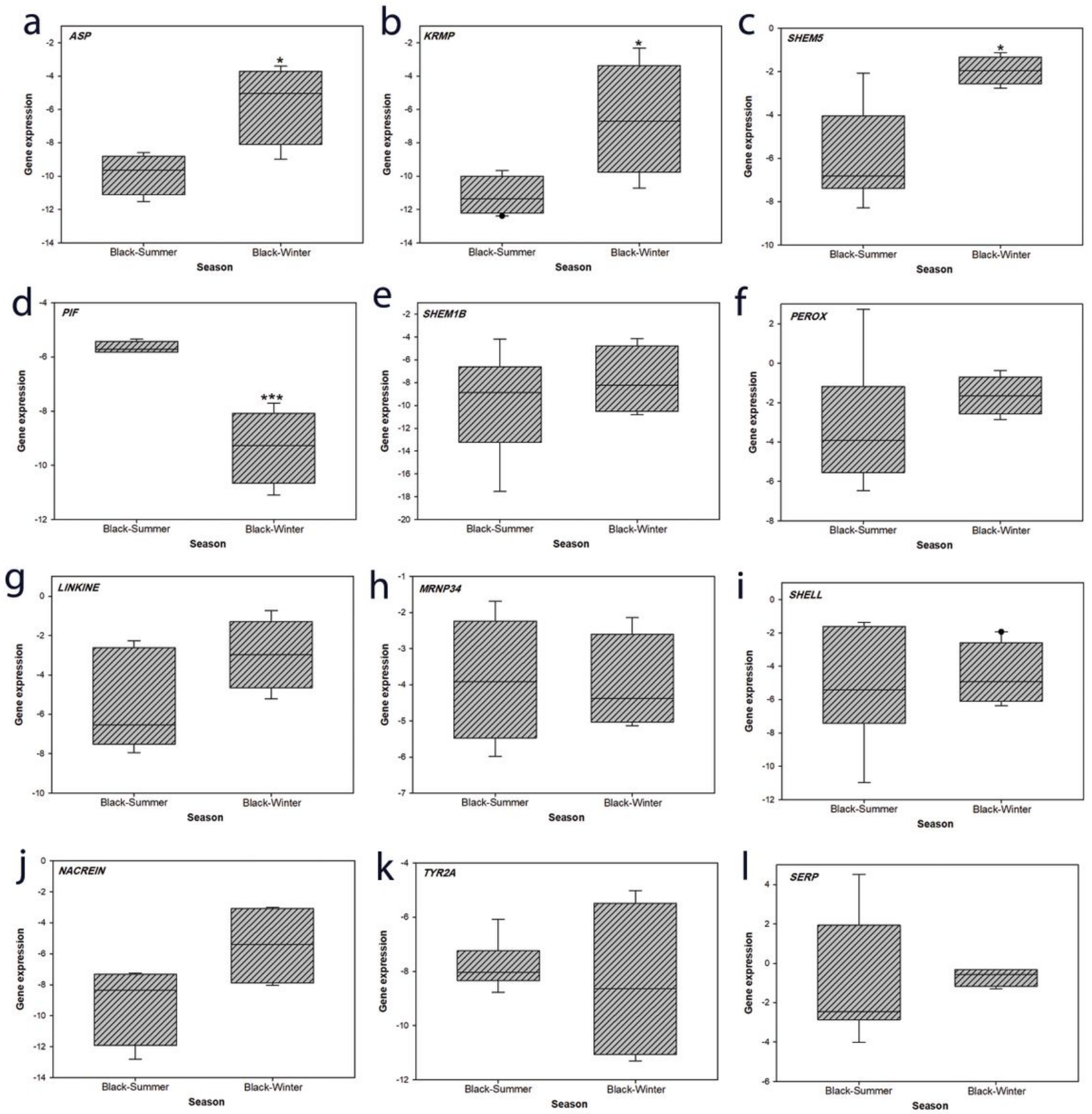

Figure 4

The box plots of the expression of genes involved in biomineralization process in black phenotypes of the pearl oyster Pinctada persica.in winter (cool) and summer (warm) seasons. Y axis is in the logarithmic scale (gene expression). Error bars indicate standard deviations. The CALM, PEARL and CHIT transcripts were not detected in the black phenotype and no PRISM mRNA expression in warm season. Statistical differences between the phenotypes are indicated by asterisks: $*: P<0.05, * * *: P<0.001$. 

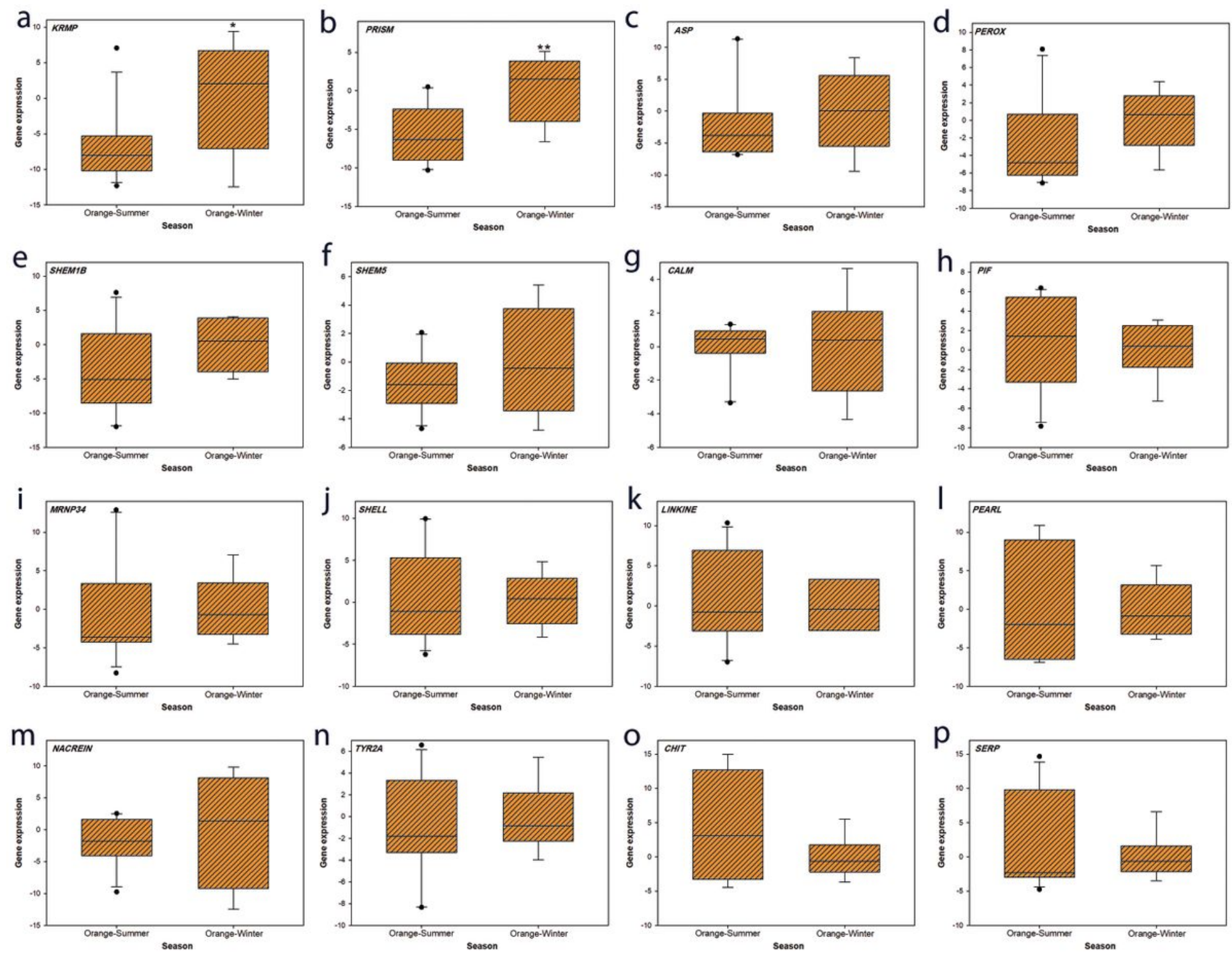

Figure 5

The box plots of the expression of genes involved in biomineralization process in orange phenotypes of the pearl oyster Pinctada persica.in winter (cool) and summer (warm) seasons. Y axis is in the logarithmic scale (gene expression). Error bars indicate standard deviations. Statistical differences between the phenotypes are indicated by asterisks: $*: P<0.05$, $\star *: P<0.01$. 


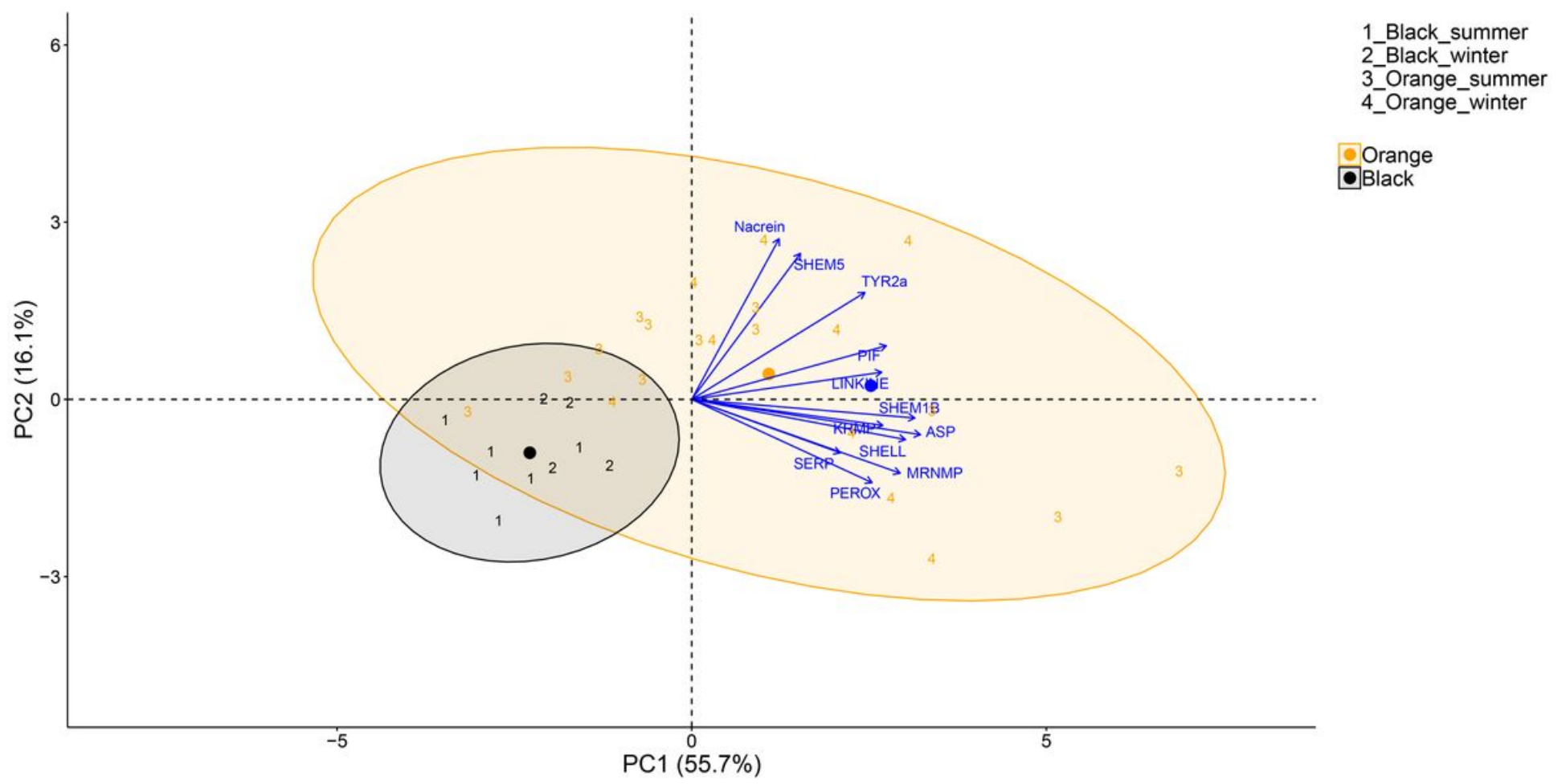

Figure 6

Canonical plots of the first two principal components of the biomineralization genes for two mantle morphs (black and orange) of the pearl oyster Pinctada persica sampled in winter (cool) and summer (warm) seasons. Principal component analysis (PCA) was performed on the entire dataset. Ellipses represent $95 \%$ confidence areas for the groups within treatments. Centroids are represented by the largest point of the same color. Arrows represent loading vectors of the genes.

\section{Supplementary Files}

This is a list of supplementary files associated with this preprint. Click to download.

- Supplementaryfigure1.docx 